NJE Vol. 35: 45-59, 2019

Nigerian Journal of Entomology

Published by the Entomology Soc. of Nig.

www.esnjournal.com.ng

DOI. 10.36108/NJE/9102/53.01.50

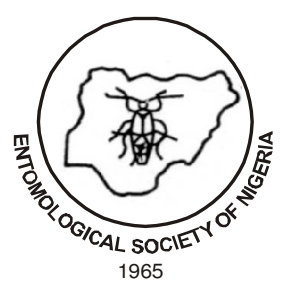

\title{
Resistance of Some Hybrid Maize (Zea mays L.) to Damage by Maize Weevil Sitophilus zeamais (Motsch.) (Coleoptera: Curculionidae) and Larger Grain Borer, Prostephanus truncatus (Horn) (Coleoptera: Bostrichidae)
}

\author{
Adebowale, T. J' ${ }^{1}$, *Osipitan, A. A. ${ }^{1}$, Pitan, O. R. ${ }^{1}$ Lawal O. I., ${ }^{2}$ Joda A. O., ${ }^{3}$ \\ Filani C. O. ${ }^{1}$ and Ewedairo, B. I. ${ }^{1}$ \\ ${ }^{I}$ Department of Crop Protection, Federal University of Agriculture, Abeokuta, Ogun State, Nigeria \\ ${ }^{2}$ Department of Plant Physiology and Crop Production, Federal University of Agriculture, \\ Abeokuta, Ogun State, Nigeria \\ ${ }^{3}$ Department of Crop Production, Faculty of Agricultural Production and Renewable Resources, \\ Olabisi Onabanjo University, Ago-Iwoye, Ogun State, Nigeria
}

\begin{abstract}
Damage to stored maize grains by Sitophilus zeamais and Prostephanus truncatus is enormous and could be total if the insects are not controlled timely and appropriately. Control of the insects with host plant resistance has advantages over other control measures because of its lasting effect, friendliness to the environment and safety to natural enemies among others. This study assessed host resistance of 11 maize varieties to infestation and damage by $S$. zeamais and $P$. truncatus. One hundred gram maize grains each of the maize varieties were weighed into $250 \mathrm{~cm}^{3}$ glass jars and separately infested with twenty, 1-5 days old $S$. zeamais or P. truncatus. Percentage grain damage, weight loss, adult mortality, grain dust and number of insects were determined and integrated to define the resistance of the maize varieties to the insects. Eight of the 11 maize varieties were either resistant or moderately resistant to damage by $S$. zeamais and $P$. truncatus, while three were susceptible. The basis of resistance is antibiosis conferred by the ash, carbohydrate and fat content of the maize grains. The resistance varieties could be planted to mitigate infestation and damage by the insects. The factors conferring resistance can be used as environmentally friendly source of resistance to breed maize grains for resistance to the insects.
\end{abstract}

Keywords: Prostephanus truncatus, Sitophilus zeamais, host plant resistance, proximate composition, resistant.

\section{INTRODUCTION}

Maize, Zea mays L., is an important crop

*Correspondence email:

osipitan1@yahoo.com ranked second in world grain production after wheat. The crop is versatile in its uses and environmental adaptation, and is an important component of agriculture and food 
systems all over the world (Makate, 2010). Storage of maize is crucial in order to maintain constant supply throughout the year for industries and household food supplies as well as to provide seeds for planting (Adetunji, 2007). However, stored grains may suffer severe infestation and damage from insect pests when not properly stored and or protected. The insects cause direct destruction of infested grains through feeding and also pre-disposes the stored grains to secondary attack by disease-causing pathogens such as mycotoxin-producing fungi; which could lead to increase in respiration and consequent loss in quantity and quality of the grains (Odogola, 1994).

The larger grain borer, Prostephanus truncatus (Horn) (Coleoptera: Bostrichidae) and maize weevil, Sitophilus zeamais (Motschulsky) (Coleoptera: Curculionidae) cause considerable economic losses to smallholder farmers in Africa by reducing the quality, market and nutritional values of infested grains (Demissie et al., 2008; Gueye et al., 2008). Prostephanus truncatus is a pest of farm stored maize and a serious pest of dried cassava chips from Central America that infest and damage maize grains and the cob both before and after harvest (Gilman, 1984). The insect is now endemic in many parts of sub-Saharan Africa (Gueye et al., 2008) and have been reported in Togo, Benin, Burkina Faso, Burundi, Ghana, Kenya, Malawi, Mozambique, Zambia, Nigeria and some Africa countries (Pike et al., 1992; Borgemeister et al., 2003). Adult LGB bore into cassava, maize husks, cob and grains making neat round holes and tunnels producing large quantities of grain dust (Boxall, 2002).

Losses due to infestation by $P$. truncatus and Sitophilus zeamais are enormous. In fermented cassava root, $P$. truncatus was reported to cause weight loss of $75 \%$ within 4 months of storage and $34 \%$ in maize stored for a period of 3-6 months in Tanzania (Hodges et al., 1985; Markham et al., 1994). Similarly, S. zeamais have been recognized as an increasingly important problem in Africa (Markham et al., 1994). The insect is responsible for heavy losses every year and worldwide grain losses of 20 to $90 \%$ have been reported for untreated maize due to infestation by S. zeamais (Giga et al., 1991; Giga and Mazarura, 1991).

Synthetic insecticides are mostly used to control P. truncatus and S. Zeamais due to their availability and rapid action. However, their widespread use for the control of stored-product insect pests is of global concern (Cherry et al., 2005). The increasing costs of synthetic insecticide is unaffordable by poor farmers and their widespread use causes environmental hazards, development of resistance, accumulation of residue in food and feed as well as their negative effects on non-target organisms (Otto, 1992). Today, there is increased public awareness and concern for the broader environmental safety with focus on the development of alternative management strategies such as the use of resistant maize varieties against insect pests of maize. Maize varieties have been reported to respond differently to insect infestation due to their morphological and biochemical constituents that confer resistance and reduced the successful utilization by insect pests (Temesgen and Waktole, 2013). A Nochoice studied that screened 20 maize varieties to infestation and damage by Angouimois grain moth, Sitotroga cerealla on the basis of moth emergence, developmental period, insect weight, weight flour, grain weight loss, grain damage and nutritional indices indicated that Pratap makka-5 was the most resistant variety having the longest developmental, minimum grain damage and lowest susceptibility index (Demissie et al., 2015). 
Resistance breeding is a promising alternative that provides economical means to minimize post-harvest losses (Mwololo et al., 2013). The use of host plant resistance for the control of insect pest is effective and may reduce the severity of infestation. The method is technically easy, economically feasible, environmentally benign and viable for the management of insect pests, especially among resource-constrained farmers (Giga et al., 1991; Pereira et al., 2009). However, the strategy of host plant resistance has been under-utilized in maize; particularly on storage pests (Pingali and Pandey, 2001). This study therefore assessed the resistance of some hybrid maize to infestation and damage by $S$. zeamais and $P$. truncatus during storage.

\section{MATERIALS AND METHODS}

\section{Location of experiment and source of maize}

The study was conducted in the Research Laboratory of the Department of Crop Protection, College of Plant Science and Crop Production, Federal University of Agriculture, Abeokuta (FUNAAB) at ambient temperature of $30-32^{\circ} \mathrm{C}$ and $68-70 \%$ relative humidity. The maize varieties used in this study were sourced from the International Institute of Tropical Agriculture (IITA), Ibadan (10) and FUNAAB (1) (Table 1).

\section{Culture of Prostephanus truncatus and Sitophilus zeamais}

The larger grain borer, $P$. truncatus and maize weevil, $S$. zeamais used for the study were obtained from stocks maintained in the Laboratory of Department of Crop Protection, College of Plant Science and Crop Production, FUNAAB and cultured in the laboratory. One hundred grams LGBsusceptible whole maize grains were weighed into $250 \mathrm{ml}$ glass bottles and separately infested with several adults of $P$. truncatus and $S$. zeamais for seven days to lay eggs; the insects were thereafter sieved out of the grains. The insects that emerged thereafter were monitored and those between the age of 1-5 days were used for the study.

\section{Evaluation of the maize genotypes for} resistance to $L G B$ in a no-choice test

One hundred (100) g maize grains were weighed into $250 \mathrm{ml}$ Kilner glass jars and infested with 20 unsexed 1-5 day old LGB. The treatments were arranged on the experimental table using Completely Randomized Design (CRD). The introduced insects were confined in the grains for 90 days and then sieved-out to separate insects, grains and maize flour. The grains were separated into damaged and undamaged. Data were collected on the following parameters:

Weight of $\operatorname{dust}(g)$ - the grain dust was sieved from the grains and weighed with a Mettler weighing balance.

Weight of damaged or undamaged grains - grain dust was sieved-out of the grains and the grains were separated into damaged and undamaged. The weight of damaged or undamaged grains were taken separately with a Mettler ${ }^{\circledR}$ weighing balance.

Number of adult larger grain borer Living and dead adults of larger grain borer were counted to determine their number.

Percentage grain damage - Percentage grain damage was computed using the formulae:

$\%$ grain damage

$$
=\frac{\text { Weight of damaged grains }}{\text { Total weight of grains }} \times 100
$$


Percentage weight loss - Percentage weight loss was calculated using the formulae:

$\%$ Weight loss

$=$ Weight of control sample - Final weight of grains

Weight of control sample

One hundred (100) g un-infested maize grains were weighed into $250 \mathrm{ml}$ Kilner glass jars and kept on work table in the laboratory throughout the experimental period. At the end of the experiment, they were weighed and the mean change in weight was used to correct for weight gain or loss due to sorption or loss in the test materials (Hurlock, 1967).

\section{Evaluation of the maize varieties for resistance to Sitophilus zeamais in a no-choice test}

One hundred (100) g maize grains were weighed into $250 \mathrm{ml}$ Kilner glass jars and infested with twenty 20 unsexed 1-5 day old $S$. zeamais. The glass jars were arranged on the experimental table using Completely Randomized Design (CRD). The introduced insects were left on the grains for 90 days. At 90 days' post-infestation, the insects were sieved-out to separate insects, grains and maize flour. The grains were separated into damaged and undamaged. Data on weight of dust, weight of damaged and undamaged grains, number of adult maize weevil were taken as indicated for $P$. truncatus. Percentage grain damage and percentage weight loss were also calculated as earlier indicated.

\section{Determination of proximate composition of maize grains}

The proximate composition of the maize varieties was determined prior to infestation by $S$. zeamais and $P$. truncatus to determine the variation in the composition of proximate of the maize varieties (Demissie et al., 2015). The grains were analyzed for moisture, ash, total protein, crude fat and crude fibre following the standard procedure of AOAC (1990).

Rating scale and resistance rating of maize genotypes to damage by Prostephanus truncatus and Sitophilus zeamais

A rating scale on a score of 1-5 based on five damage indices (adult mortality, grain damage, number of adult $P$. truncatus, weight of grain dust, grain weight) according to Osipitan and Odebiyi (2007) was used to score and rate the maize varieties for resistance to damage by $P$. Truncates and $S$. zeamais (Table 2). Five groups were determined according to Sturges (1926) formula for determination of class interval using $\mathrm{n}=1+3.332 \log \mathrm{N}$, where $\mathrm{N}$ is the total number of treatments which is 11 and $n$ is the number of groups. The number of groups (n) is therefore $1+3.332(1.042)=1+3.472$, $\mathrm{n}=4.472$. The group of 5 was used as rating scales incen is greater than 4 . The weighted average score was generated and used for rating the maize varieties into one of the four widely recognized classes of resistance: highly resistant, resistant, moderately resistant and susceptible (Osipitan and Odebiyi, 2007).

\section{Statistical Analysis}

Statistical analysis of data was based on SAS general statistical linear models procedure (SAS, 2001). Analysis of variance (ANOVA) table was generated for all the variable treatments at $\mathrm{P} \leq 0.05$ and Duncan Multiple Range Test (DMRT) was used to separate significant means. Data on all insect counts were transformed using square root transformation and all data in percentages were arcs in transformed before subjection to ANOVA. Indices of grain damage such as percentage weight loss, percentage damage 
and weight of dust generated were correlated with population of adult LGB and adult $S$. zeamais (Demissie et al., 2015).

\section{RESULTS}

\section{Number of Adult LGB and Sitophilus zeamais}

Number of adult $P$. truncatus differ significantly $(\mathrm{P}<0.05)$ between the varieties (Table 3). SUWAN-1-SR has the highest number (152.67) of adult while 2000SYNEE-WSTR and TZEEYPOPSTRQPM CO has the lowest number (38.33 and 38.33 respectively) of adult $P$. truncatus. There were no significant $(\mathrm{P}<0.05)$ difference in the percentage mortality of all the maize varieties except 2000SYNEE-W QPMCO and 2009TZEEW-STR (Table3). The percentage mortality of adult $P$. truncatus was highest in the variety 2000SYNEE-WQPMCO (31.19\%) and lowest $(5.54 \%)$ in the variety 2009TZEE-W-STR. The number of adult $S$. zeamais on the maize varieties differed significantly $(\mathrm{P}<0.05)$. The number of the insect (152.67) in variety SUWAN 1-SR was significantly higher, the number of the insect in the other maize varieties except the number (132.67) in TZEE-W POP STR $\mathrm{C}_{5}$. The percentage mortality of adult $S$. zeamais were however, not $(\mathrm{P}>0.05)$ significantly different irrespective of the maize variety except SUWAN-1-SR (Table 3).

\section{Damage assessment in maize grains infested with LGB and Sitophilus zeamais} The percentage grain damage of 16.23 by $P$. truncatus in TZEE-W-POP-STRC5 was significantly higher $(\mathrm{P}<0.05)$ than the percentage grain damage in other maize genotypes, while SUWAN-1-SR has a significantly $(\mathrm{P}<0.05)$ lower percentage grain damage of 7.15 (Table 4 ). The percentage grain damage in "2008TZEE Y-STR" and "SUWAN-1-SR" were not significantly
(P>0.05) different from each other (Table 4). Similarly, the weight $(1.63 \mathrm{~g})$ of grain dust in SUWAN-1-SR infested with $P$. truncatus was significantly $(\mathrm{P}<0.05)$ lower than the weight of grain dust in all other maize varieties (Table 4). The percentage grain weight loss of 1.7 in the maize variety "SUWAN-1-SR" was significantly $(\mathrm{P}<0.05)$ lower than the weight losses in all other maize varieties (Table 4). The grain weight losses in the maize genotypes "2004 TZEEYPOPSTR C4”," 2009TZEE-W-STR C4”, "99TZEE-Y STR" and "2000SYNEEWQPMCO" damaged by $P$. truncatus were not $(\mathrm{P}>0.05)$ significantly different from each other (Table 4).

The percentage grain damage due to the feeding activities of $S$. zeamais differed significantly $(\mathrm{P}<0.05)$ among all the maize varieties except "2009TZEE-W-STR" and "2000SYNEE-WQPM CO" (Table 4). The grain damage in "TZEE-W-POP-STRC5" was significantly $(\mathrm{P}<0.05)$ lower than the damage in other maize varieties, while the damage was significantly $(\mathrm{P}<0.05)$ higher in "2000SYNEE-WSTR". The weight of grain dust in "TZEE-WPOPSTRC5", and “2008TZEEY-STR”, 2004 were not (P>0.05) significantly different from each other (Table 4). Similarly, weight of grain dust in TZEEYPOPSTRC4, 2009TZEE-WSTR, 2004 TZEE-WPOPSTRC4，2000SYNEE-WQPM CO, 2008SYNEE-YDTSTR and TZEEYPOPSTRQPMCO were not significantly (P>0.05) different from each other (Table 4). The percentage weight loss was significantly $(\mathrm{P}<0.05)$ higher in the maize varieties "2008TZEE Y-STR" and significantly $(\mathrm{P}<0.05)$ lower in the maize varieties "2000 SYNEE-W STR" (Table 4).

\section{Proximate composition of maize grains}

The proximate composition of the eleven maize genotypes shows that the moisture 
content of the maize varied between 10.08 and 13.01 (Table 5). The moisture content of SUWAN-1-SR was significantly $(\mathrm{P}<0.05)$ higher than the moisture content of others. The protein content varied between 9.63 and 17.51. The maize variety 2004TZEE-W POP STR C4 has a significantly lower protein content of 9.63, while 2009TZEE-WSTR and 2000SYNEE-W QPMCO has a significantly $(\mathrm{P}<0.05)$ higher protein content of 17.51 (Table 5). The fat content (1.52) in the variety "2009 TZEE-WSTR" was significantly $(\mathrm{P}<0.05)$ higher than the fat content in other maize varieties. The crude fibre varied between 3.40 and 8.18, with the maize variety "SUWAN-1-SR" and TZEEYPOPSTRQPMCO possessing significantly $(\mathrm{P}<0.05)$ higher and lower content of 3.40 and 8.18 respectively (Table 5). The maize variety 2004TZEE-YPOPSTRC4 has significantly higher ash content of 9.92, while 2000SYNEE-WQPMCO and TZEEYPOPSTRQPMCO has significantly lower ash content of 1.65. The carbohydrate content of 68.60 in the maize variety "2008SYNEE-YDTSTR" and 68.41 in "2000SYNEE-QPMCO" were not significantly $(\mathrm{P}>0.05)$ different from each other, but were significantly $(\mathrm{P}<0.05)$ higher that the carbohydrate contents of other maize varieties (Table 5).

\section{Correlation of grain damage index and number of $P$. truncatus and Sitophilus zeamais}

The correlation $(r=0.67699)$ between weight of damaged grains and number of living $P$. truncatus, number of living $P$. truncatus and weight of dust $(\mathrm{r}=0.93074)$, number of living $P$. truncatus and $\%$ weight loss $(\mathrm{r}=0.53487)$, weight of damaged grains and weight of grain dust $(\mathrm{r}=0.57591)$ were positive and highly significant (Table 6). The correlation of weight of grain dust and \% weight loss in maize grains damaged by $P$. truncatus $(\mathrm{r}=0.49493)$, and weight of maize grains damaged by $P$. truncatus and grain weight loss were positive and significant $(\mathrm{r}=0.51024)$ (Table 6). In maize grains infested with $S$. zeamais, the correlation $(r=0.40771)$ between weight of damaged grains and number of living insects, weight of dust and number of living insects, $(\mathrm{r}=0.4393), \%$ weight loss and number of living insects $(\mathrm{r}=0.41400)$, weight of damaged grains and weight of grain dust $(\mathrm{r}=0.33608)$, weight of dust and \% weight loss $(r=0.40074)$, weight of damaged grains and grain weight loss $(\mathrm{r}=0.70258)$ were positive and significant (Table 6).

\section{Correlation of proximate composition of maize grains with grain damage by Prostephanus truncatus and Sitophilus zeamais}

The correlation of ash, carbohydrate and fat contents of maize grains with grain damage by $P$. truncates was positive and significant $(\mathrm{r}=0.3575,0.6134$ and 0.50696 respectively) (Table 7). The correlations of protein, crude fibre and moisture contents with damage by $P$. truncatus were not significant $(\mathrm{r}=0.228$, -0.01000 and -0.03318 respectively). The correlation of carbohydrate content of maize grains with damage caused by $S$. zeamais was positive and significant $(\mathrm{r}=0.1985)$. The correlation of ash, protein, crude fibre, moisture and fat contents were insignificant $(\mathrm{r}=-0.2967,0.2686,-0.2927,-0.01327$ and 0.04470 respectively) (Table 7 ).

Eight of the eleven maize varieties were resistance or moderate resistance to damage by $P$. truncatus and $S$. zeamais, while three were susceptible based on the resistance index. The three maize varieties TZEEWPOPSTRC5, 2004TZEE-YPOPSTRC4 and 2009TZEE-WSTR were susceptible to damage by $P$. truncatus, while eight other ones were either resistance or moderately 
resistance to the insect (Table 8). The eight maize varieties that were resistance or moderately resistance to $S$. zeamais are 2004TZEE-YPOPSTRC4, 2009TZEEWSTR, 2004TZEE-WPOP STR C4, 99TZEE-YSTR, 2000 SYNEE-WQPMCO, 2008 SYNEE-YDT STR,2000 SYNEEWSTR and SUWAN-1-SR. The susceptible ones are TZEE-WPOPSTR C5.2008TZEEYSTR and TZEE-YPOPSTR QPMCO (Table 9). The maize variety "TZEE-Y-
POPSTRQPMCO" was resistant to damage by $P$. truncatus, but was susceptible to damage by $S$. zeamais, while the variety 2009TZEE-W-STR was susceptible to damage by $P$. truncates but was moderately resistant to damage by $S$. zeamais. SUWAN 1-SR and 2000 SYNEE-W-STR were resistant to both insects, while 2004TZEEWPOPSTRC4 and 99TZEE-YSTR were moderately resistant to both insects (Tables 8 and 9).

Table 1: Names and description of maize varieties used for the study

\begin{tabular}{|c|c|c|}
\hline Variety & Source & Colour \\
\hline TZEE-W POP STR C ${ }_{5}$ & IITA, Ibadan & White \\
\hline 2004 TZEE-Y POP STR C 4 & IITA, Ibadan & Yellow \\
\hline 2009 TZEE-W STR & IITA, Ibadan & White \\
\hline 2004 TZEE-W POP STR C ${ }_{4}$ & IITA, Ibadan & White \\
\hline 99 TZEE-Y STR & IITA, Ibadan & Yellow \\
\hline 2008 TZEE Y-STR & IITA, Ibadan & Yellow \\
\hline 2000 SYNEE-W QPM CO & IITA, Ibadan & White \\
\hline 2008 SYNEE-Y DT STR & IITA, Ibadan & Yellow \\
\hline 2000 SYNEE-W STR & IITA, Ibadan & White \\
\hline TZEE-Y POP STR QPM CO & IITA, Ibadan & Yellow \\
\hline SUWAN-1-SR & FUNAAB & Yellow \\
\hline
\end{tabular}

Table 2: Rating scale for indices of parameters used in determining resistance to damage by Prostephanus truncatus and Sitophilus zeamais

\begin{tabular}{lccccc}
\hline & \multicolumn{5}{c}{ Prostephanus truncatus } \\
\cline { 2 - 6 } Score & Adult mortality & $\begin{array}{c}\text { \% Grain } \\
\text { damage }\end{array}$ & $\begin{array}{c}\text { Number of adult } \\
\text { P. truncatus }\end{array}$ & $\begin{array}{c}\text { Weight of } \\
\text { grain dust }\end{array}$ & $\begin{array}{c}\text { \% Grain } \\
\text { weight loss }\end{array}$ \\
\hline 1 & $25.64-32.04$ & $0.00-3.50$ & $0.00-26.80$ & $0.00-2.10$ & $0.00-1.21$ \\
2 & $19.23-25.63$ & $3.51-7.01$ & $26.81-53.61$ & $2.11-4.21$ & $1.22-2.43$ \\
3 & $12.82-19.22$ & $7.02-10.52$ & $53.62-80.42$ & $4.22-6.32$ & $2.44-3.65$ \\
4 & $6.41-12.81$ & $10.53-14.03$ & $80.43-107.23$ & $6.33-8.43$ & $3.66-4.87$ \\
5 & $0.00-6.40$ & $14.04-17.54$ & $107.24-134.04$ & $8.44-10.54$ & $4.88-6.09$ \\
& & & Sitophilus zeamais & & \\
Score & Adult mortality & \% Grain & Number of adult & Weight of & \% Grain \\
& & damage & S. zeamais & grain dust & weight loss \\
\hline & & & & \\
1 & $2.84-3.54$ & $0.00-15.00$ & $0.00-87.50$ & $0.00-0.70$ & $0.00-5.40$ \\
2 & $2.13-2.83$ & $15.01-30.01$ & $87.51-175.01$ & $0.71-1.41$ & $5.42-10.81$ \\
3 & $1.42-2.12$ & $30.02-45.02$ & $175.02-262.52$ & $1.42-2.12$ & $10.82-16.22$ \\
4 & $0.71-1.41$ & $45.03-60.00$ & $262.53-350.03$ & $2.13-2.83$ & $16.23-21.63$ \\
5 & $0.00-0.70$ & $60.04-75.04$ & $350.04-437.54$ & $2.84-3.54$ & $21.64-27.04$ \\
\hline
\end{tabular}


Table 3: Number of Prostephanus truncatus and Sitophilus zeamais in infested maize grains

\begin{tabular}{|c|c|c|c|c|}
\hline \multirow[t]{2}{*}{ Varieties } & \multicolumn{2}{|c|}{ Prostephanus truncatus } & \multicolumn{2}{|c|}{ Sitophilus zeamais } \\
\hline & Number of adult & $\%$ Mortality & Number of adult & $\%$ Mortality \\
\hline TZEE-W POP STR $\mathrm{C}_{5}$ & $132.67 \pm 63.23 \mathrm{ab}$ & $12.14 \pm 7.66 \mathrm{ab}$ & $389.67 \pm 48.66 \mathrm{a}$ & $2.37 \pm 0.35 a$ \\
\hline 2004 TZEE-Y POP STR C 4 & $94.33 \pm 29.68 b$ & $10.84 \pm 6.00 \mathrm{ab}$ & $435.67 \pm 46.63 b$ & $2.68 \pm 1.03 \mathrm{a}$ \\
\hline 2009 TZEE-W STR & $91.33 \pm 17.62 b$ & $5.54 \pm 1.21 b$ & $422.00 \pm 61.58 b$ & $2.41 \pm 0.80 \mathrm{a}$ \\
\hline 2004 TZEE-W POP STR C 4 & $65.33 \pm 8.08 b c$ & $13.56 \pm 4.62 \mathrm{ab}$ & $423.67 \pm 50.27 b$ & $1.83 \pm 0.49 \mathrm{a}$ \\
\hline 99 TZEE-Y STR & $64.33 \pm 22.51 b c$ & $17.46 \pm 11.30 \mathrm{ab}$ & $437.33 \pm 21.45 b$ & $2.83 \pm 0.96 a$ \\
\hline 2008 TZEE Y-STR & $50.00 \pm 29.14 b c$ & $18.23 \pm 7.74 \mathrm{ab}$ & $326.00 \pm 24.00 \mathrm{a}$ & $2.60 \pm 0.31 \mathrm{a}$ \\
\hline 2000 SYNEE-W QPM CO & $46.33 \pm 23.39 b c$ & $31.19 \pm 9.11 \mathrm{a}$ & $367.67 \pm 36.67 a$ & $2.93 \pm 0.58 \mathrm{a}$ \\
\hline 2008 SYNEE-Y DT STR & $42.67 \pm 13.01 b c$ & $15.80 \pm 6.38 \mathrm{ab}$ & $374.67 \pm 10.10 \mathrm{a}$ & $3.07 \pm 1.24 \mathrm{a}$ \\
\hline 2000 SYNEE-W STR & $38.33 \pm 3.38 \mathrm{c}$ & $15.90 \pm 3.88 \mathrm{ab}$ & $379.33 \pm 63.80 \mathrm{a}$ & $2.84 \pm 0.38 \mathrm{a}$ \\
\hline TZEE-Y POP STR QPM CO & $38.33 \pm 6.43 c$ & $13.80 \pm 2.08 \mathrm{ab}$ & $394.00 \pm 35.10 \mathrm{ab}$ & $1.82 \pm 0.32 \mathrm{a}$ \\
\hline SUWAN-1-SR & $152.67 \pm 8.33 \mathrm{a}$ & $17.32 \pm 8.52 \mathrm{ab}$ & $415.00 \pm 2.51 \mathrm{a}$ & $3.37 \pm 0.39 c$ \\
\hline
\end{tabular}

Means with the same letters along the column are not significantly different at $\mathrm{P}<0.05$ using DMRT.

Table 4: Assessment of damage in maize grains infested with Prostephanus truncatus and Sitophilus zeamais

\begin{tabular}{|c|c|c|c|c|c|c|}
\hline \multirow[t]{2}{*}{ Varieties } & \multicolumn{3}{|c|}{ Prostephanus truncatus } & \multicolumn{3}{|c|}{ Sitophilus zeamais } \\
\hline & $\begin{array}{l}\text { \% Grain } \\
\text { Damage }\end{array}$ & $\begin{array}{l}\text { Weight of } \\
\text { grain dust (g) }\end{array}$ & $\begin{array}{l}\% \text { Weight } \\
\text { loss }\end{array}$ & $\begin{array}{l}\% \text { Grain } \\
\text { Damage }\end{array}$ & $\begin{array}{l}\text { Weight of gra } \\
\text { dust (g) }\end{array}$ & $\begin{array}{l}\text { 1\% Weight } \\
\text { loss }\end{array}$ \\
\hline TZEE-W POP STR C5 & $16.23 \pm 5.24 \mathrm{a}$ & $10.22 \pm 3.55 \mathrm{a}$ & $2.47 \pm 1.21 \mathrm{f}$ & $62.55 \pm 3.81 \mathrm{i}$ & $3.30 \pm 1.04 \mathrm{a}$ & $24.36 \pm 6.47 \mathrm{c}$ \\
\hline 2004 TZEE-YPOP STRC4 & $15.79 \pm 0.88 b$ & $9.79 \pm 1.62 b$ & $4.86 \pm 2.37 \mathrm{~b}$ & $68.56 \pm 1.45 \mathrm{~d}$ & $1.57 \pm 0.14 \mathrm{de}$ & $15.36 \pm 0.32 \mathrm{~g}$ \\
\hline 2009 TZEE-W STR & $14.87 \pm 2.72 \mathrm{c}$ & $9.63 \pm 2.13 \mathrm{c}$ & $4.92 \pm 1.00 \mathrm{~b}$ & $69.06 \pm 8.95 \mathrm{c}$ & $1.95 \pm 0.43 \mathrm{~cd}$ & $23.19 \pm 8.97 d$ \\
\hline 2004 TZEE-WPOP STR C4 & $9.71 \pm 0.83 \mathrm{e}$ & $6.80 \pm 1.26 \mathrm{e}$ & $6.06 \pm 0.97 \mathrm{a}$ & $64.20 \pm 7.29 \mathrm{~g}$ & $1.58 \pm 0.25 \mathrm{cde}$ & $16.16 \pm 4.20 \mathrm{f}$ \\
\hline 99 TZEE-Y STR & $10.20 \pm 2.50 \mathrm{~d}$ & $7.98 \pm 2.79 \mathrm{~d}$ & $4.95 \pm 1.32 b$ & $72.60 \pm 1.74 b$ & $2.48 \pm 0.30 b$ & $10.55 \pm 1.95 \mathrm{~h}$ \\
\hline 2008 TZEE Y-STR & $7.12 \pm 3.41 \mathrm{~g}$ & $6.06 \pm 2.40 f$ & $4.43 \pm 0.84 \mathrm{c}$ & $62.95 \pm 6.03 h$ & $3.18 \pm 0.76 \mathrm{a}$ & $26.53 \pm 9.05 a$ \\
\hline 2000 SYNEE-W QPM CO & $6.18 \pm 1.48 \mathrm{i}$ & $3.86 \pm 1.57 \mathrm{i}$ & $4.89 \pm 2.73 b$ & $68.92 \pm 2.08 \mathrm{c}$ & $1.96 \pm 0.33 \mathrm{~cd}$ & $24.81 \pm 2.92 b$ \\
\hline 2008 SYNEE-Y DT STR & $6.36 \pm 2.32 \mathrm{~h}$ & $4.43 \pm 1.36 \mathrm{~h}$ & $3.62 \pm 0.42 \mathrm{~d}$ & $63.21 \pm 1.54 \mathrm{~h}$ & $1.91 \pm 0.45 \mathrm{~cd}$ & $21.69 \pm 4.43 \mathrm{e}$ \\
\hline 2000 SYNEE-W STR & $9.56 \pm 2.16 f$ & $5.52 \pm 0.73 \mathrm{~g}$ & $2.93 \pm 1.00 \mathrm{e}$ & $73.01 \pm 1.83 \mathrm{a}$ & $2.07 \pm 0.33 \mathrm{bc}$ & $5.06 \pm 3.36 \mathrm{i}$ \\
\hline TZEE-Y POP STR QPM CO & $4.35 \pm 1.44 \mathrm{j}$ & $3.32 \pm 0.76 \mathrm{j}$ & $3.18 \pm 0.27 \mathrm{e}$ & $67.96 \pm 0.61 \mathrm{e}$ & $1.94 \pm 0.50 \mathrm{~cd}$ & $16.02 \pm 3.95 f$ \\
\hline SUWAN-1-SR & $7.15 \pm 2.33 \mathrm{~g}$ & $1.63 \pm 1.64 \mathrm{k}$ & $1.70 \pm 0.55 \mathrm{~g}$ & $67.48 \pm 2.28 \mathrm{f}$ & $1.22 \pm 1.11 \mathrm{e}$ & $7.15 \pm 2.22 \mathrm{j}$ \\
\hline
\end{tabular}

Means with the same letters along the column are not significantly different at $\mathrm{P}<0.05$ using DMRT. 
Table 5: Proximate composition of maize grains infested with Prostephanus truncatus and Sitophilus zeamais

\begin{tabular}{lllllll}
\hline & \multicolumn{7}{l}{ Proximate Composition Of Maize Grains (\%) } \\
\cline { 2 - 7 } Varieties & Moisture & $\begin{array}{l}\text { Crude } \\
\text { Protein }\end{array}$ & Fat & $\begin{array}{l}\text { Crude } \\
\text { Fibre }\end{array}$ & Ash & Carbohydrate \\
\hline TZEE-W POP STR C 5 & $10.66 \mathrm{f}$ & $16.46 \mathrm{~b}$ & $0.95 \mathrm{~b}$ & $5.40 \mathrm{e}$ & $7.60 \mathrm{~d}$ & $58.93 \mathrm{j}$ \\
2004 TZEE-Y POP STR C 4 & $10.69 \mathrm{e}$ & $14.71 \mathrm{~d}$ & $0.00 \mathrm{~d}$ & $4.63 \mathrm{~g}$ & $8.92 \mathrm{a}$ & $61.05 \mathrm{i}$ \\
2009 TZEE-W STR & $10.43 \mathrm{~h}$ & $17.51 \mathrm{a}$ & $1.52 \mathrm{a}$ & $4.50 \mathrm{~h}$ & $2.07 \mathrm{~h}$ & $63.97 \mathrm{f}$ \\
2004 TZEE-W POP STR C 4 & $11.61 \mathrm{c}$ & $9.63 \mathrm{i}$ & $0.00 \mathrm{~d}$ & $4.90 \mathrm{f}$ & $7.66 \mathrm{c}$ & $66.20 \mathrm{c}$ \\
99 TZEE-Y STR & $10.99 \mathrm{~d}$ & $15.59 \mathrm{c}$ & $0.00 \mathrm{~d}$ & $4.00 \mathrm{i}$ & $8.33 \mathrm{~b}$ & $61.09 \mathrm{i}$ \\
2008 TZEE Y-STR & $10.53 \mathrm{~g}$ & $14.71 \mathrm{~d}$ & $0.00 \mathrm{~d}$ & $6.00 \mathrm{~d}$ & $4.98 \mathrm{f}$ & $63.78 \mathrm{~g}$ \\
2000 SYNEE-W QPM CO & $10.19 \mathrm{j}$ & $17.51 \mathrm{a}$ & $0.00 \mathrm{~d}$ & $8.00 \mathrm{~b}$ & $1.65 \mathrm{j}$ & $62.65 \mathrm{~h}$ \\
2008 SYNEE-Y DT STR & $10.08 \mathrm{k}$ & $12.37 \mathrm{~g}$ & $0.00 \mathrm{~d}$ & $7.02 \mathrm{c}$ & $5.65 \mathrm{e}$ & $64.88 \mathrm{~d}$ \\
2000 SYNEE-W STR & $10.23 \mathrm{i}$ & $14.01 \mathrm{f}$ & $0.48 \mathrm{c}$ & $4.90 \mathrm{f}$ & $1.78 \mathrm{i}$ & $68.60 \mathrm{a}$ \\
TZEE-Y POP STR QPM CO & $12.21 \mathrm{~b}$ & $14.33 \mathrm{e}$ & $0.00 \mathrm{~d}$ & $3.40 \mathrm{j}$ & $1.65 \mathrm{j}$ & $68.41 \mathrm{a}$ \\
SUWAN-1-SR & $13.01 \mathrm{a}$ & $10.21 \mathrm{~h}$ & $0.00 \mathrm{~d}$ & $8.18 \mathrm{a}$ & $4.13 \mathrm{~g}$ & $64.47 \mathrm{e}$ \\
Mean & $10.97 \mathrm{~b}$ & $13.24 \mathrm{~b}$ & $0.27 \mathrm{a}$ & $5.54 \mathrm{~b}$ & $4.94 \mathrm{~b}$ & $64.01 \mathrm{~b}$ \\
\hline
\end{tabular}

Means with the same letters along the column are not significantly different at $\mathrm{P}<0.05$ using DMRT.

Table 6: Correlation of index of grain damage with number of Prostephanus truncatus and Sitophilus zeamais

\begin{tabular}{lllll}
\hline $\begin{array}{l}\text { Prostephanus } \\
\text { Truncatus }\end{array}$ & $\begin{array}{l}\text { Number of } \\
\text { living insect }\end{array}$ & $\begin{array}{l}\text { Weight of } \\
\text { damaged grains }\end{array}$ & $\begin{array}{l}\text { Weight of } \\
\text { grain dust }\end{array}$ & $\begin{array}{l}\text { \% Grain } \\
\text { weight loss }\end{array}$ \\
\hline $\begin{array}{l}\text { Number of living P. truncatus } \\
\text { Weight of damaged grains }\end{array}$ & 1.000 & $0.67699^{* *}$ & $0.93074^{* *}$ & $0.53487^{* *}$ \\
$\begin{array}{l}\text { Weight of grain dust } \\
\text { \% Grain weight loss }\end{array}$ & & 1.000 & $0.57591^{* *}$ & $0.51024^{*}$ \\
& & & 1.000 & $0.49493^{*}$ \\
Sitophilus zeamais & & & & 1.000 \\
$\begin{array}{l}\text { Number of living S. zeamais } \\
\text { Weight of damaged grains }\end{array}$ & 1.00 & $0.40771^{*}$ & $0.4393^{*}$ & $0.41400^{*}$ \\
$\begin{array}{l}\text { Weight of grain dust } \\
\text { \% Grain weight loss }\end{array}$ & & 1.00 & $0.33608^{*}$ & $0.70258^{*}$ \\
\end{tabular}

** Significant at $\mathrm{p} \leq 0.01$

* Significant at $\mathrm{p} \leq 0.05$ 
Table 7: Correlation of proximate composition of maize grains with grain damage of Prostephanus truncatus and Sitophilus zeamais

\begin{tabular}{llllllll}
\hline Insect & \multicolumn{7}{c}{ Proximate Composition } \\
\cline { 2 - 7 } & Damage & Ash & Protein & Carbohydrate & Crude fibre & Moisture Content & Fat \\
\hline P. truncatus & Grain & $0.3575^{*}$ & 0.228 & $0.6134^{*}$ & -0.01000 & -0.03318 & $0.50696^{*}$ \\
S. zeamais & Grain & -0.2967 & 0.2686 & $0.1985^{*}$ & -0.2927 & -0.01327 & 0.04470 \\
\hline
\end{tabular}

$* *$ Significant at $\mathrm{p} \leq 0.01$

* Significant at $\mathrm{p} \leq 0.05$

Table 8: Resistance rating of eleven maize varieties to damage by Prostephanus truncates

\begin{tabular}{|c|c|c|c|c|c|c|c|}
\hline Maize Variety & $\begin{array}{c}\text { Insect } \\
\text { mortality }\end{array}$ & $\begin{array}{l}\% \text { grain } \\
\text { damage }\end{array}$ & $\begin{array}{c}\text { Number } \\
\text { of adult } \\
\text { LGB }\end{array}$ & $\begin{array}{l}\text { Weight of } \\
\text { grain dust }\end{array}$ & $\begin{array}{c}\% \text { grain } \\
\text { weight } \\
\text { loss }\end{array}$ & $\begin{array}{l}\text { Weighted } \\
\text { average }\end{array}$ & $\begin{array}{l}\text { Resistance } \\
\text { rating }\end{array}$ \\
\hline TZEE-W POP STR $\mathrm{C}_{5}$ & 4 & 5 & 5 & 5 & 3 & 4.4 & Susceptible \\
\hline 2004 TZEE-Y POP STR $C_{4}$ & 4 & 5 & 4 & 5 & 5 & 4.6 & Susceptible \\
\hline 2009 TZEE-W STR & 5 & 5 & 4 & 5 & 5 & 4.8 & Susceptible \\
\hline 2004 TZEE-W POP STR C ${ }_{4}$ & 3 & 3 & 3 & 4 & 5 & 3.6 & $\begin{array}{l}\text { Moderately } \\
\text { resistant }\end{array}$ \\
\hline 99 TZEE-Y STR & 3 & 3 & 3 & 4 & 5 & 3.6 & $\begin{array}{l}\text { Moderately } \\
\text { resistant }\end{array}$ \\
\hline 2008 TZEE Y-STR & 3 & 3 & 2 & 4 & 4 & 3.2 & $\begin{array}{l}\text { Moderately } \\
\text { resistant }\end{array}$ \\
\hline 2000 SYNEE-W QPM CO & 1 & 2 & 2 & 2 & 5 & 2.4 & resistant \\
\hline 2008 SYNEE-Y DT STR & 3 & 2 & 2 & 3 & 3 & 2.6 & resistant \\
\hline 2000 SYNEE-W STR & 3 & 3 & 2 & 3 & 3 & 2.8 & resistant \\
\hline TZEE-Y POP STR QPM CO & 3 & 2 & 2 & 2 & 3 & 2.4 & resistant \\
\hline SUWAN-1-SR & 2 & 3 & 4 & 1 & 2 & 2.4 & resistant \\
\hline
\end{tabular}

Table 9: Resistance rating of eleven maize varieties to damage by Sitophilus zeamais

\begin{tabular}{|c|c|c|c|c|c|c|c|}
\hline Maize Variety & $\begin{array}{c}\text { Insect } \\
\text { mortality }\end{array}$ & $\begin{array}{l}\% \text { grain } \\
\text { damage }\end{array}$ & $\begin{array}{c}\text { Number } \\
\text { of adult } \\
\text { LGB }\end{array}$ & $\begin{array}{c}\text { Weight } \\
\text { of grain } \\
\text { dust }\end{array}$ & $\begin{array}{c}\% \text { grain } \\
\text { weight } \\
\text { loss }\end{array}$ & $\begin{array}{l}\text { Weighted } \\
\text { average }\end{array}$ & $\begin{array}{l}\text { Resistance } \\
\text { rating }\end{array}$ \\
\hline TZEE-W POP STR $\mathrm{C}_{5}$ & 2 & 5 & 5 & 5 & 5 & 4.4 & Susceptible \\
\hline 2004 TZEE-Y POP STR $C_{4}$ & 2 & 5 & 5 & 3 & 3 & 3.6 & $\begin{array}{l}\text { Moderately } \\
\text { resistant }\end{array}$ \\
\hline 2009 TZEE-W STR & 2 & 5 & 4 & 3 & 5 & 3.8 & $\begin{array}{l}\text { Moderately } \\
\text { resistant }\end{array}$ \\
\hline 2004 TZEE-W POP STR C 4 & 3 & 5 & 4 & 3 & 4 & 3.8 & $\begin{array}{l}\text { Moderately } \\
\text { resistant }\end{array}$ \\
\hline 99 TZEE-Y STR & 1 & 5 & 5 & 3 & 5 & 3.8 & $\begin{array}{l}\text { Moderately } \\
\text { resistant }\end{array}$ \\
\hline 2008 TZEE Y-STR & 2 & 5 & 4 & 5 & 5 & 4.2 & Susceptible \\
\hline 2000 SYNEE-W QPM CO & 1 & 5 & 5 & 3 & 5 & 3.8 & $\begin{array}{l}\text { Moderately } \\
\text { resistant }\end{array}$ \\
\hline 2008 SYNEE-Y DT STR & 1 & 5 & 5 & 3 & 5 & 3.8 & $\begin{array}{l}\text { Moderately } \\
\text { resistant }\end{array}$ \\
\hline 2000 SYNEE-W STR & 1 & 5 & 4 & 3 & 1 & 2.8 & Resistant \\
\hline TZEE-Y POP STR QPM CO & 3 & 5 & 5 & 3 & 4 & 4.0 & Susceptible \\
\hline SUWAN-1-SR & 1 & 5 & 4 & 2 & 2 & 2.8 & resistant \\
\hline
\end{tabular}




\section{DISCUSSION}

In this study, eight of the eleven maize varieties were either resistance or moderately resistance to damage by $P$. truncatus and $S$. zeamais, while three were susceptible based on the resistance index. The result is inconsonance with that of Kumar (2002) which indicated that 19 landraces from the Caribbean showed resistance to $P$. truncatus. In a similar study, Kasambala (2009) screened some maize varieties for susceptibility to $P$. truncatus and reported that nine commercial maize hybrids, namely SC403, SC407, SC513, SC627, SC717, DK8033, DK8053, DK8073, MH18 were susceptible to the insect, and a local variety "Kanjerenjere" was resistant. Derera et al. (2000) and Abebe et al. (2009) have also reported existence of variation for resistance to damage by stored product insects among maize genotypes. Nhamucho et al. (2014) reported the existence of resistance to infestation and damage by $P$. truncatus among maize genotypes in Mozambique.

The variation in the damage by $P$. truncatus and $S$. zeamais to the maize grains suggest differences in the genetic make up of the maize varieties. This substantiate the results of earlier study by Osipitan and Odebiyi (2007) which indicated that ICW5BC2-B(KU1414) was not damaged by $P$. truncatus and did not have grain dust nor lost weight among twenty maize genotypes screened for damage by the insect. Luke et al. (2015) similarly reported highest weevil mortality, reduced percent grain damage, no weight loss, no powdering and no oviposition in two maize genotypes "2000SYNEE-WSTR" and "TZBRELD3C5". Adedire et al. (2011) reported that TZBRELD3C was highly resistant to $S$. zeamais. Dhliwayo and Pixley (2003) reported that the existence of resistance to maize weevil in maize genotypes materials will make improvement of resistance against maize weevil possible. The maize genotype "2000SYNEE-WSTR" classified as resistant in this study was also classified as resistant in a separate study by Nwosu et al. (2015) and Luke et al. (2015). Ewedairo et al. (2014) also reported relative resistance of the maize genotype "SUWAN-1-SR" to damage by $P$. truncatus among nine maize genotypes screened for resistance to damage by the insect. The results of this study show that some of the maize varieties such as SUWAN-1-SR-Y and 2000SYNEE-W-STR were resistant to both insects, while 2004TZEE-WPOPSTRC4 and 99 TZEEYSTR were moderately resistant to the insects. This suggests that maize could demonstrate dual resistance to damage by $P$. truncates and $S$. zeamais. This possibility could be explored by seed breeders to breed maize varieties that have multiple resistance to infestation and damage by the insects. The maize genotypes SUWAN 1-SR and 2009TZEE-W-STR that were resistance to damage by $P$. truncatus and $S$. zeamais notably had relative lower grain damage, grain weight loss, weight of grain dust, final number of adult insects and higher mortality compared to the susceptible ones. In a similar study, Nwankwo et al. (2014) reported relatively low number of adult, low weight loss and damaged seeds in five maize varieties that were resistance to damage by $P$. truncatus.

The weight loss (1.70-6.06\%), grain damage (4.35-16.23\%) and grain dust (1.63$10.22 \mathrm{~g}$ ) in the maize genotypes infested with $P$. truncatus, and weight loss (5.06-26.53\%), grain damage (62.55-73.01\%) and grain dust $(1.22-3.30 \mathrm{~g})$ in the maize genotypes infested with $S$. zeamais. This is similar to earlier reports by McFarlane (1989), Denning et al. (2009) and APHLIS (2015) on the ability of $P$. truncatus to damage maize. Delima (1987) and Giga et al. (1991) indicated that 
maize grains damaged by $S$. zeamais have reduced nutritional values, low percent germination, reduced weight and market values and reported worldwide seed losses of 20 to $90 \%$ for untreated maize due to $S$. zeamais infestation. In this study, higher number of $P$. truncatus and $S$. zeamais stimulated higher grain damage, grain dust and weight loss. In a similar study, Dushyant et al. (2009) reported positive correlation between weight loss and adult emergence of S. oryzae, while Tefera et al. (2011) indicated that the level of damage and weight loss during storage is strongly correlated with the number of adult insects.

The proximate composition of the maize genotypes indicated variation in the ash, protein, fat, crude fibre, carbohydrate and moisture contents. This is in agreement with the result of Nwankwo et al. (2014) which indicated that ten maize varieties differed in their overall chemical and physical parameters and their responses to $P$. truncatus. Similarly, Nwankwo et al. (2015) and Luke et al. (2015) reported differences in the chemical composition of maize grain screened for infestation and damage by $S$. zeamais and $P$. truncatus. The variation in the damage to the maize genotypes by the insects suggest that the chemical composition of the maize grains may likely influence damage by the insects and their population. The results suggest supportive influence of carbohydrate content on damage by $P$. truncatus and $S$. zeamais. In a similar study, Pamidi et al. (2016) reported positive correlation of starch to susceptibility parameters and concluded that $S$. zeamais showed preference to maize with high starch content. Similarly, Osipitan and Odebiyi (2007) and Chijindu and Boateng (2008) reported the role of starch content of maize grains as a susceptible factor to storage pests. Chalfant and Gaines (1973) reported that $P$. truncatus responded in general to odours from starchy commodities and Scholz et al. (2009) reported that breeding by adults of $P$. truncatus was dependent on the high starch content of the wood of Manihot esculenta. Similarly, Ichiro et al. (2009) reported that insects consume starch and protein from grains to grow and for laying eggs.

The influence of fat and ash content on damage by $P$. truncatus was supportive. However, the influence of ash content on damage by $S$. zeamais was suppressive, though not significant and the effect of fat was also insignificant. This suggests that the influence of some bio-chemical composition of maize grains on $P$. truncatus and $S$. zeamais differed. The influence of protein content of the maize grains on damage by the insects was positive and insignificant. Siwale et al. (2009) and Luke et al. (2015) however reported significant positive correlation between protein and insect damage suggesting protein as a basis of susceptibility. The results are however at variance with the reports of Dobie (1977) and Arnason et al. (2004) which reported negative relationship between protein content and susceptibility index. From the results of the study, it could be concluded that some of the maize varieties are resistance to damage by $P$. truncatus and $S$. zeamais. The basis of resistance is antibiosis conferred by the ash, carbohydrate and fat content of maize grains. The factors conferring resistance can be used to breed maize grains that are resistant to $P$. truncatus and S. zeamais.

\section{REFERENCES}

Abebe, F.T., Teheran, S., Mugo, Y. B. and Vidal, S. (2009). Resistance of maize varieties to the maize weevil, Sitophilus zeamais Motsch (Coleoptera: Curculionidae). African Journal of Biotechnology, 8: 5937-5943.

Adedire, C. O., Akinkurolere, R. O. and Ajayi, O. O. (2011). Susceptibility of some maize cultivars in Nigeria to infestation and 
damage by maize weevil, Sitophilus zeamais (Motsch.) (Coleoptera: Curculionidae). Nigerian Journal of Entomology, 28: 55-63.

Adetunji, M. (2007). Economics of maize storage techniques by farmers in Kwara State, Nigeria. Pakistan Journal of Social Sciences, 4, 442-450.

AOAC (1990). Official methods of analysis of the Association of Official Analytical Chemists, 15th Edition, AOAC, Arlington, Virginia.

APHLIS (2015). African Post-Harvest Losses Information System. Available at http://www.aphlis.net. Accessed on 6 March, 2015.

Arnason, J. T., Baum, B., Gale, J., Lambert, J.D.H., Bergvinson, D., Philogene, B.J.R., Serratos, J.A., Mihm, J. and Jewell, D.C. (2004). Variation in resistance of Mexican land races of maize to maize weevil Sitophilus zeamais, in relation to taxonomic and biochemical parameters. Euphytic,74: 227-336.

Borgemeister, C., Holst, N. and Hodges, R.J. (2003). Biological control and other pest management options for Larger grain borer, Prostephanus truncatus. In: Biological control in IPM systems in Africa (Neuenschwande P., Borgemeister C., and Langewald, J. eds), CAB International, Wallingford Oxon., pp. 311-328.

Boxall, R.A. (2002). Damage and loss caused by the larger grain borer Prostephanus truncatus. Integrated Pest Management Review 7: 105-21.

Chalfant, R.B. and Gaines, T.P. (1973). Cowpea curculio: correlation between chemical composition of the southern pea and varietal resistance. Journal of Economic Entomology, 66 (5): 1011-1013.

Cherry, A.J., Bantino, A.,Djegui, D. and Lomers C. (2005). Suppression of the stemborer Sesamia calamistis (Lepidoptera: Noctuidae) in maize following seed dressing, topical application and stem injection with African isolates of Beauveria bassiana. International Journal of Pest Management, 50: 67-73.

Chijindu, E.N. and Boateng, B.A. (2008). Effect of nutritional content of processed cassava chips on development of
Prostephanus truncates (Horn). World Journal of Agricultural Science, 4:404-408.

Delima, C.P.F. (1987). Insect pests and postharvest problems in the tropics. Insect Science and its Application, 8: 673- 676.

Demissie, G., Tefera, T. and Tadesse, A. (2008). Importance of husk covering on field infestation of maize by Sitophilus zeamais Motsch. (Coleoptera: Curculionidae) at Bako, Western Ethiopia. African Journal of Biotechnology, 7: 37743779.

Demissie, G., Swaminathan, R., Ameta, O. P., Jain, H. K., and Saharan, V. (2015). Biochemical basis of resistance in different varieties of maize for relative susceptibility to Sitotroga cerealella (Olivier) (Lepidoptera: Gelechiidae). Journal of Stored Products and Post Harvest, 6(1): $1-12$

Derera, J., Pixley, K.V. andG iga, P.D. (2000). Resistance of maize to the maize weevil: I. Antibiosis. African Crop Science Journal, 9: 431-440.

Dhliwayo, T. and Pixley, K.V. (2003). Divergents election for resistance to maize weevil in six maize populations. Crop Science, 43: 2043-2049.

Denning, G., Kabambe, P., Sanchez, P., Malik, A. and Flor, R. (2009). Input subsidies to improve small holder maize productivity in Malawi: Towards an African green revolution. Public Library of Science Biology 7(1): e1000023.doi:10.1371/ journal.pbio.1000023.Available at http:// www.plosbiology.org. Accessed on 30 June 2010. Public Library of Science, USA.

Dobie, P. (1977). The laboratory assessmen of the inherent susceptibility of maize varieties to post-harvest infestation by Sitophilus zeamais Motschulsky (Coleoptera: Curculionidae. Journal of Stored Products Research, 10: 183-197.

Dushyant, K., Sharma, R.K., Rajvanshi, S.K. and Sharma, K. (2009). Evaluation of maize germplasms for resistance against Sitophilus oryzae (L.). Annals Plant Protection Science, 17: 75-77.

Ewedairo, B.I., Osipitan, A.A., Pitan, O.R., Adebisi, M.A. and Atayese, M.O. (2014). Evaluation of the nutritional composition of maize (Zeamays) kernels and their 
resistance to damage by larger grain borer Prostephanus truncates Horn (Coleoptera: Bostrichidae). Nigerian Journal for Plant Protection, 24 (1): 34-44.

Giga, D.P. and Mazarura, U.M. (1991). Levels of resistance to the maize weevil, Sitophilus zeamais (Motsch.) in exotic, local open pollinated and hybrid maize germ plasm. Insect Science and its Application, 12: 159169.

Giga, D.P., Mutumeerwa, S., Moya, G. and Neeley D. (1991). Assessment and control of losses caused by insect pests in small farmers, stores in Zimbabwe. Crop Protection, 10: 287-292.

Gilman, G.A. (1984). The occurrence and economic importance of Prostephanus truncatus. Supra-regional effort to hinder further spread in Africa. Proceedings of International Seminar on the larger grain borer, P. truncatus, Lome, Togo.

Gueye, M.T., Goergen, G., Badiane, D., Hell, K. and Lamboni L. (2008). First report on occurrence of the larger grain borer Prostephanus truncates (Horn) (Coleoptera: Bostrichidae) in Senegal. African Entomology, 16, 309-311.

Hodges, R.J., Meik, J. and Denton H. (1985). Infestation of dried cassava (Manihote sculenta Crantz) by Prostephanus truncates (Horn) (Coleoptera: Bostrichidae). Journal of Stored Products Research, 21: 73-74.

Hurlock, E.T. (1967). Some observations on the amount of damage caused by Oryzaephilus surinamensis (L.) (Coleoptera: Silvidae) to wheat. J. Stored Pro. Res., 3: 75-78.

Ichiro, M.,Tomiko, Toshiaki, O., Tomoko, T. and Keiko, A. (2009). Catheps in D-like aspartic proteinase occurring in a maize weevil, Sitophilus zeamais, as a candidate digestive enzyme. Bioscience, Biotechnology and Biochemistry, 73: 2338-2340.

Kasambala, T. (2009). Prostephanus truncates (Horn) (Coleoptera: Bostrichidae) infestation levels on different maize varieties in Malawi. Resistant Pest Management Newsletter 19 (1): 9-13. Center for Integrated Plant Systems (CIPS).

Kumar, H. (2002). Resistance in maize to the larger grain borer, Prostephanus truncates (Horn) (Coleoptera: Bostrichidae). Journal of Stored Products Research, 38: 267-280.
Luke, C.N., Chris, O.A. and Emmanuel, O.O. (2015). Screening for new sources of resistance to Sitophilus zeamais Motschulsky (Coleoptera: Curculionidae) infestation in stored maize genotypes. Journal of Crop Protection, 4 (3): 277-290.

Makate, N. (2010). The susceptibility of different maize varieties to postharvest infestation by Sitophilus zeamais (Motsch) (Coleoptera: Curculionidae). Science and Research Essay, 5: 30-34.

Markham, R.H., Bosque-Pérez, N., Borgemeister, C. and Meikle, W.G. (1994). Developing pest management strategies for the maize weevil, Sitophilus zeamais and the larger grain borer, Prostephanus truncatus, in the humid and sub-humid tropics. FAO Plant Protection Bulletin, 42: 97-116.

McFarlane, J.A.(1989). Guidelines for pest management research to reduces to red food losses caused by insects and mites. Overseas Development Natural Resources Institute Bulletin, 22:62.

Mwololo, J. K., Mugo, S., Tefera, T. and Munyiri, S.W. (2013). Evaluation of traits of resistance to postharvest insect pests in tropical maize. International Journal of Agriculture and Crop Sciences, 6: 926-933.

Nhamucho, C., Mugo, S., Kinyua, M., Gohole, L., Tefera, T. and Mulima, E. (2014). Antibiosis mechanism for resistance to larger grain borer, Prostephanus truncates (Horn) (coleoptera: Bostrichidae) in maize. Journal of Entomology, 11: 248-260.

Nwankwo, E.N., Egwuatu, R.I., Okonkwo, N.J. and Boateng, B.A. (2014). Screening of ten maize varieties Zeamays (L.) for resistance against Prostephanus truncates (Horn) (Coleoptera: Bostrichidae) from different zones of Nigeria and Ghana. Academic Journal of Entomology,7(1): 1726.

Nwankwo, E.N., Okonkwo, N.J. and Egwuatu, R.I. (2015). Integration of Pyrethroid Insecticides Combined With Host Plant Resistance in the Management of the Larger Grain Borer, Prostephanus Truncatus (Horn) (Coleoptera: Bostrichidae), on Stored Maize, Zea Mays L. Journal of Entomology and Zoology Studies, 3(4): 98105. 
Nwosu, C., Adedire, C.O. and Ogunwolu, E.O. (2015). Screening for new sources of resistance to Sitophilus zeamais Motschulsky (Coleoptera: Curculionidae) infestationins to red maize genotypes. Journal of Crop Protection, 4: 277-290.

Odogola, W.R. (1994). Postharvest management and storage of food legumes. Technical Systems for Agriculture. AGROTEC UNDP/OPS, Harare, Zimbabwe.

Osipitan, A.A. and Odebiyi, J.A. (2007). Laboratory evaluation of twenty maizes (Zeamays L.) varieties for resistance to the larger grain borer, Prostephanus truncates (Horn) (Coleoptera: Bostrichidae), in Ibadan, Oyo State, Nigeria. Nigerian Journal of Entomology, 24: 54-67.

Otto, D. (1992). Insektizid resisyenzin Insekten population-en-einuberblick. Nachrichten blattdes Dt. Pflanzen-Schutzdienstes, 44(2): 34-39.

Pamidi, L.S., Javaji, C.S., Chikkappa, G.K., Dharam, P. and Pradyumn, K. (2016). Evaluation of biophysical, anatomical and biochemical traits of resistance to Sitophilusoryzae L. (Coleoptera: Curculionidae) in stored maize, Maydica, 61.

Pereira, C., Perereira, E., Cordeiro, E., Lucia, T.D., Tótola, M. and Guedes R. (2009). Organophosphates resistance in the maize weevil, Sitophilus zeamais (Coleoptera: Curculionidae): magnitude and behavior. Crop Protection, 28,168-173.

Pike, V., Akinningbagbe, J.J.A. and BosquePerez, N.A. (1992). Outbreaks and Records: Largergrain borer (Prostephanus truncatus) in Western Nigeria. FAO Plant Protection Bulletin, 40(4): 170-173.
Pingali, P.L. and Pandey, S. (2001). Meeting world maize needs: Technology opportunities and priorities for the public sector. In: World maize facts and trends. Meeting world maize needs: Technological opportunities and priorities for the public sector. Pingali PL ed. CIMMYT, Mexico DF.

SAS (2001). SAS users guide statistics, 6th edition. SAS Institute Inc., Cary, NC.

Scholz, D., Tchabi, A., Borgemester, C., Markham, R.H., Poehling, H.M. and Lawson, A. (2009). Host-finding behavior of Prostephanus truncates (Horn) (Coleoptera: Bostrichidae): Primary attraction or random attack? Journal of Applied Entomology, 121(5): 261-269.

Siwale, J., Mbata, K., Mcrobert, J. and Lungu, D. (2009). Comparative resistance of improved maize genotypes and Landraces to maize weevil. African Crop Science Journal, 17, 1-16.

Sturges, H.A. (1926). The choice of a class interval. Journal of American Statistical Association, 21: 65-66.

Tefera, T., Mugo, S., Likhayo, P. (2011). Effects of insect population density and storage time on grain damage and weight loss in maize due to the maize weevil Sitophilus zeamais and the larger grain borer - Prostephanus truncatus. African Journal of Agricultural Research, 6: 22492254.

Temesgen, K. and Waktole, S. (2013). Differential Resistance of Maize Varieties to Maize Weevil (Sitophilus zeamais Motschulsky) (Coleoptera: Curculionidae) under Laboratory Conditions. Journal of Entomology, 10: 1-12.
NJE Vol. 35: 45-59, 2019

Nigerian Journal of Entomology

Published by the Entomology Soc. of Nig.

www.esnjournal.com.ng

DOI. 10.36108/NJE/9102/53.01.50

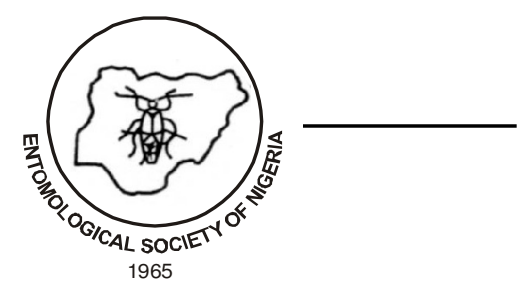

